\title{
Curbing Fraudulent Practices through Accountability in Non-Profit Making Organizations
}

\author{
JOLOKO, Bisola Grace* \\ Department Accounting \& Finance, Caleb University Lagos \\ AUDU, Solomon Ibrahim \\ Department of Accounting \& Finance, Caleb University Lagos
}

\begin{abstract}
This study seeks to examine the ways to curb fraudulent practices among Not for Profit Organizations (NPOs) through the accountability processes. NPOs are one of the least regulated sectors of the economy making them prone to incidences of fraud which are often undetected within the poor accountability system. It is imperative to examine the nature and negative effects of fraud to stakeholders who have placed their trust on the activities of the non-profit organizations but are unable to obtain justification of their activities because funds are not judiciously utilized for the purpose they were raised. The study particular considered the perspective of chartered accountants by arguing that have a significant role in understanding the accountability framework for fraud prevention and control in NPOs. The population of the study consist of all chartered accountants of ICAN in Ikorodu and a questionnaire was administered to the participants. Regression analysis was used to test the relationship between accountability processes (internal audit, governance, external audit and regulatory process) and fraudulent practices among NPOs. The results of the analysis showed that there is no relationship between accountability framework variables - internal audit, governance and the regulatory process, however external audit showed a significant relationship with the fraudulent practices in NPOs. The study recommended that external audit be made mandatory for NPOs amongst other recommendation.
\end{abstract}

Keywords: Fraud, Accountability, Non-profit making organization, Governance, Stakeholders

DOI: $10.7176 / \mathrm{RJFA} / 10-14-01$

Publication date:July $31^{\text {st }} 2019$

\section{Introduction}

The non-profit making sector has an important role to contribute in fulfilling the desire of the social community whether it is religious, health, educational and other human service organizations. The non-profit making organizations differentiate themselves from profit oriented companies in that they exist to pursue missions that satisfy shortfalls of the society. Not-for-profit entities contribute to the development of our communities in order to enhance the quality of life. Not-for-profit organizations come in a variety of sectors, such as religious, health, social services, commerce, education, sports, clubs, cooperatives and the arts. Not-for-profits are not owned on a commercial basis and mostly rely on members' subscriptions and contributions, program incomes, grants which could be public or private, other fundraising events and income from such investments.

These category of organizations rely on appointed board of trustees and management officers in preserving of the entity's resources.

In Nigeria, the growing incidence of corporate fraud has meant that investors' confidence in the capital market has waned (Okaro, Okafor, and Ofoegbu, 2013). In fact, the current down turn in the market has been blamed partly on the fraud at the Nigerian Stock Exchange (Osaze, 2011). While more attention of fraud cases is reported in the profit making sector, little cases of fraud have been reported of non-for-profit making organizations in various Nigerian dailies with purported Naira sums reported across various not-for profit making organizations such as NNPC Cooperative society, Nigeria police cooperative multipurpose society etc. In view of the importance of the not-for profit making organizations contribution to the overall development of our environment and adverse effect of the practice of fraud on the going concern of any organization.

Fraudulent financial reporting practices has dire consequences for the economy of any Nation and the victim organizations. Its effects include financial loss and dent on the reputation of the victim organization (Burnaby et al., 2011). According to Greenlee, Keating, and Gordon (2007) little empirical research has been conducted to examine the few instances of fraud among nonprofit organizations and whether fraud is comparatively less prevalent in the nonprofit sector. Non-profits are all run by human beings regardless of their mission, people make them exist. It is the duty of the stakeholders and the society at large to appreciate and recognize that individual people are the foundation of all actions in the not-for-profit entity. In this modern setup of running entities there is no noticeable difference in how a profit and not-for-profit organizations are run, they are just the same Dzomira (2014).

Incidence of fraud in whatsoever way it is been examined from leads to loss on the organization (NGOs, cooperative societies, Foundations, unions, associations etc.) its members and the community in general. The loss 
on the organization arises from the fact that it reduces the financial ability of the organization and tarnishes the reputation of the organization thereby leading to loss of public confidence in the organization. The impact of loss due to fraudulent practice on the members of such organization also affects them adversely i.e. rights or benefits to be enjoyed by such members might be denied or not fully met such as access to low rate loans etc. On the part of the community, it means that certain contributions expected to be met by such organizations won't be adequately met and also in addition to this, tax waivers given to such organizations in order to promote their activities for the well-being of the society will also be in vain.

Despite the level of funds channeled through Non-profit organizations, fraud and corruption continue to be a highly sensitive topic in this sector of the economy. Extant literature has shown that the threat level of money laundering and terrorist financing risk in the Nigerian NP) sector is rated medium-high. This is mostly because of the weak and ineffective monitoring measures for the regulation of nonprofit activities. It is also important to note that many of NPOs do not directly address or disclose fraud practices among which the following types of fraud have become common: Inflated, duplicate, or fictitious invoices for goods and services procured for a project, "ghost" employees, participants or beneficiaries, Kickback arrangements in procurement of goods or services or in hiring of project staff, "Double-dipping", or seeking or accepting funds from more than one donor for (parts of) the same project and even fictitious NGOs, or politically connected organizations set up to win public contracts (including those setup to act as delivery partners for NGOs).

It is also a source of great concern that many organizations that fall within the purview of NGOs are opposed to a formalized and specific regulatory framework, this impeded the level of accountability that exist in this sector. It is tedious and elusive to track the activities of these organizations effectively; matching expenditure against their perceived income has been reported to be quite difficult. Also in 2016, there was a code of corporate governance released by the Financial reporting council of Nigeria (FRCN). In view of all these, this study is aimed at establishing the existence of fraud in Non-profit making organizations in Nigeria, examining the effectiveness of the code of conduct published by the FRCN and also prescribing ways for better accountability system in the nonprofit making organizations. This study will reveal the effectiveness of the corporate code of conduct for nonprofit making organizations in Nigeria and also identify the methods used in carrying out fraudulent practices in NPOs. As a result of these, it will aid regulators focus on lapses in setting up regulations to promote regulations that will establish improved level of accountability and also aid accountants in practice to watch out for identified fraudulent practice techniques. In addition to all these, the study is aimed at adding to the existing body of literature as a reference point for future studies.

Hence the need for this study which is posed at seeking measures to strengthen accountability as a means of curbing fraudulent practices among non-profit making organizations. The main aim of this study is to proffer ways to strengthen accountability and hence curb fraudulent practice in not-for profit making organizations in Nigeria. In achieving this, the following specific objectives are set to be accomplished;

1. Establish the relevance of internal control on fraudulent practices in Nigerian not-for profit making organizations NPOs;

2. Identify the importance of good governance on fraudulent practices among NPOs in Nigeria;

3. Evaluate the effectiveness external audit on fraudulent practices on NPOs in Nigeria; \&

4. Assess the necessity for regulatory process in curbing fraudulent practices of NPOs in Nigeria.

1.1. Research Hypotheses

1. H0: There is no significant relationship between internal audit and fraudulent practices in Nigerian not-for profit making organizations.

2. H0: Good governance does not have any significant relationship with fraudulent practices being carried out in Nigerian NPOs.

3. H0: There is no significant relationship between external audit and fraudulent practices among NPOs in Nigeria.

4. H0: Regulatory process does not have a significant relationship with fraudulent practices among NPOs in Nigeria.

\subsection{Literature Review}

As cited by Greenlee, Keating, and Gordon (2007), Fraud is defined in Miriam-Webster's Dictionary of Law (1996) as "any act, expression, omission, or concealment calculated to deceive another to his or her disadvantage." Also Dzomira (2014), defined it as an act of artifice (trickery or guile) to defraud or deceit encountered in misrepresentation which is normally intentional, or concealment of documents, or non-disclosure for the purpose of inducing another or to surrender a legal right or obtaining money or other properties through false pretenses, representations or promises. Accountability on the other hand is achieved through the preparation of stewardship reports which shows the economical state of affairs of the entity. Internal audit, governance, external audit and the regulatory process are seen as mechanisms to ensure that the stewardship report are done regularly and that they 
actually represent real life economic situation.

\subsection{Theoretical Review}

1.3.1. Fraud Triangle Theory

As noted by Dzomira (2014), this theory states that many frauds do share common traits in nature, which comprises of three elements which are;

1.Motivation/Perceived Pressures/Incentive

\section{Opportunity}

\section{Justification/ Rationalization}

\subsubsection{Lending Credibility Theory}

This theory is premised on the notion that the primary function of audit is to give credibility to the financial statements. It simply means that the process of the external audit is to boost confidence in the stewardship report prepared affirming that it is the true economical state of the firm.

\subsection{Conceptual Model}

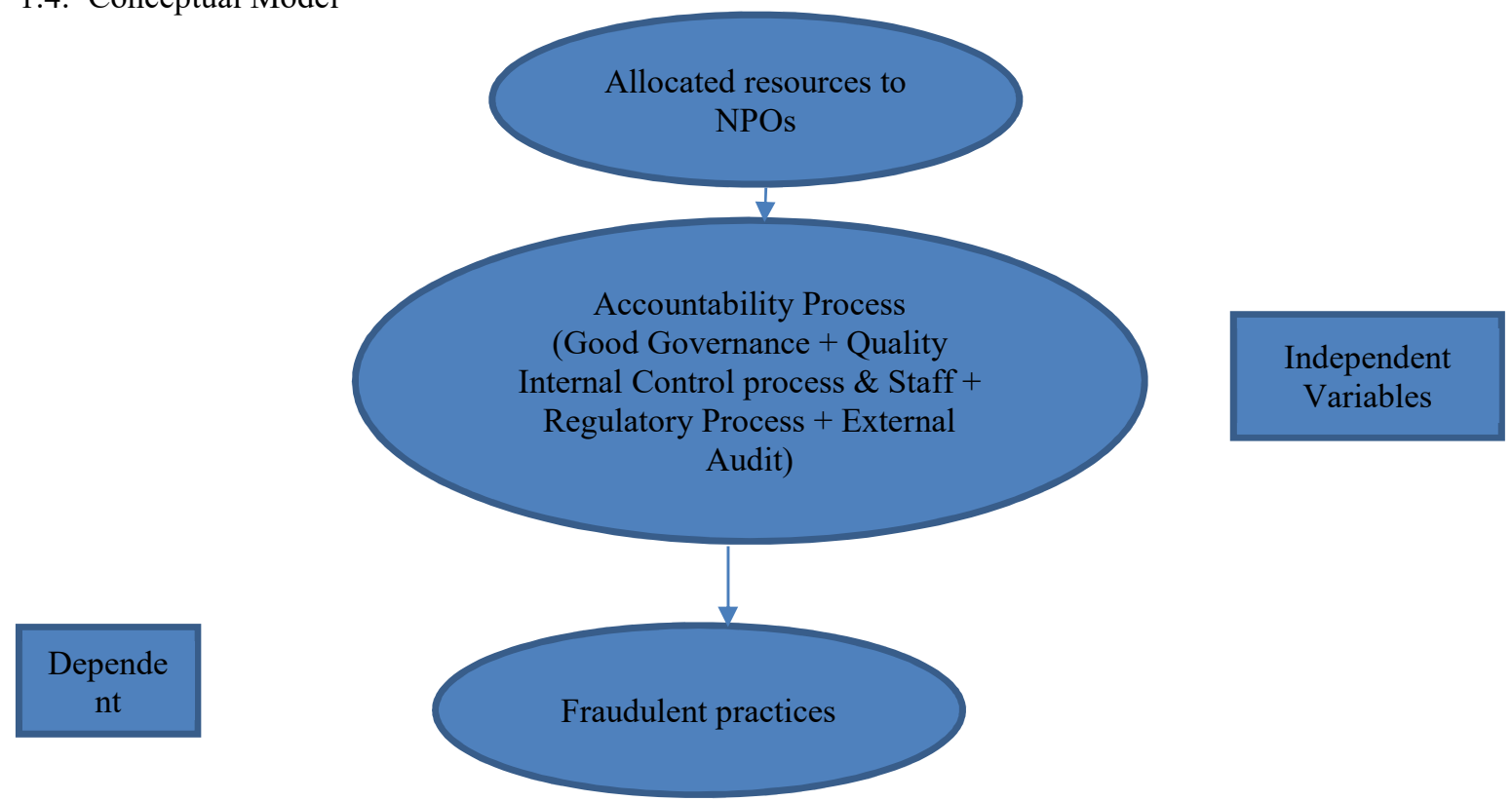

\subsection{Empirical Review}

Studies from various countries have shown that fraud exists majorly in the financial industry but with little focus on the non-profit making organizations. Greenlee, Keating, and Gordon (2007) stated that few empirical research work has been done in establishing the level of fraud done in the non-profit making sector of economies. Morehead (2007), carried out a similar study with the aim of examining internal control principles and components, along with the history of fraud and corruption. The study was borne as a result Transparency International Corruption Perceptions Index (CPI), where American-based NGOs are operating in inherently corrupt countries of the world. The study showed that weaknesses exist in these NGOs' internal control systems, the NGOs have not capitalized on the strengths of strong internal control system components; and, their operations in international settings need stronger internal control systems. It was recommended that there was need for strengthening of the internal control systems in NGOs. Though the finding, it didn't specify on what components of the internal control needed strengthening also this study focus was on a selected few American NGOS.

Furthermore, Greenlee, Fischer, Gordon, \& Keating (2007), carried out a study to report on the types of fraud they identified in nonprofit organizations and the characteristics of both the victims and the perpetrators of the fraudulent activities in the United States America They made use of the survey method and their study was borne out of losses due to fraudulent activities that were particularly troublesome in the nonprofit sector. The result of their findings showed that all of the reported frauds were committed by employees, managers, or executives of the victimized organization. They recommended that governing boards are urged to consider important controls in addition to maintaining a good public view by producing credible and reliable financial information.

Dzomira (2014) examined the effectiveness of the general internal controls such as control environment, risk assessment, control activities, information and communication and monitoring of NGOs . A qualitative method was used to carry out the study which was borne out of the need to x-ray fraud which has become a cause of 
concern despite the nature and type of business being carried by any organization. It was discovered that it was crucial for the entity to develop a sound and effective internal control system to manage such risks. And recommended that the not-for-profit control system should be visible to the key stakeholders of the entity such as the suppliers, donors, financiers, members and even recipients. And despite the size or mission of the not-for-profit organization, policies and procedures to govern operations should be established. Application of the COSO model was encouraged. However, the study cannot be generalized as it was carried out using a qualitative method thus the findings were done inductively and not scientifically which might be subject to the researchers' bias.

In Kenya, Otieno \& Nyangechi (2013), studied the effectiveness of internal control procedures on management efficiency of FPE funds in public primary schools in Kisii Central District. It was borne out of concerns over misappropriation and misuse of Free Primary Education funds having been raised by parents, the government and donors despite the increased funding programs were not fully implemented. The study showed that use of internal control procedures is effective on management efficiency of funds in schools. Thus they recommended embracing enhanced internal control procedures in their resolve to efficient management. However, the study was focused on Kenya Education fund.

Also, in Uganda, Etengu \& Amony (2016), carried out a study to investigate the role of internal control system in the financial performance of non-governmental organizations in Uganda. Their study was borne out of the concern that little is known about the influences of internal control systems and financial performance of NGOs in Uganda. They carried the study using survey method and discovered that a significant relationship exists between control environment, control activities, monitoring, and financial performance. They recommended that control environment, control activities, and monitoring should be enhanced in order to further improve the financial performance of NGOs. However, full generalization of their findings cannot be adopted as it was limited to just the Ugandan environment and information was gotten from just an NGO.

In Nigeria, Okaro, Okafor, \& Ofoegbu, (2013), conducted a study with the aim of comparing corporate fraud in a profit making organization and a non-profit making organization in the particular circumstances of a developing country like Nigeria with a view to drawing out the similarities and differences between them. The study was carried out using as case study to see management involvement in Fraud. It was discovered that the crooks were top management of both organizations under review. They recommended regulation to monitor the activities of the management of the NPOs. However, the study was just focused on the Nigerian stock exchange which is not representative of NGOs in Nigeria given the fact that it is just one out of many.

Further to Okaro et al (2013) study was a survey research carried out by Ojua (2016), with the aim of investigating the issue of controls and frauds by assessing whether churches have effective internal controls and if such can prevent fraud.it was borne out of the need to measure Non-profit organizations particularly the ecclesiastical arm lack internal control. It was discovered that internal controls in these churches are based on trust and not on the basic accounting principles hence they are not in a position to maximize the effectiveness of internal controls to their advantage. They recommended that churches need to work particularly on the authorization and personnel controls to avoid incidence of fraud. However, the result of the findings is limited on just religious NGOs and not covering the various forms of religious institutions as it focuses on just churches.

From these studies across continents i.e. America and Africa, we can establish that fraud is not strange to NPOs, there is a strong relationship between the level of fraudulent practice and the presence of internal control and that internal controls in NPOs fails mostly in the personnel and authorization component. As the control structures are not to formal and are built based on close relationship and trust of control staff and management who are susceptible to fraud.

\subsection{Methodology}

A quantitative research design was used which is to involve a field survey which will be conducted on members of the ICAN in Ikorodu district society. The study population for the survey consists of 208 active members of ICAN Ikorodu district society who are all chartered accountants and assumed to be knowledgeable in financial matters across various business entities form. Probability sampling was used in drawing the sample, with the parameters set at $95 \%$ confidence level and 5\% confidence interval which led to a sample size of 71 . Primary data to be used in this study were gathered with the aid of a questionnaire. The research instrument has a five-point Likert scale in the forms of Strongly Agree, Agree, Undecided, Disagree and Strongly Disagree, and with the corresponding values of $5,4,3,2,1$, respectively. The questionnaire was administered using the electronic mail method. The justification for using the questionnaire is to get the perception of knowledgeable persons who have experience of financial matters across varying business forms.

\subsection{Statistical Tool and Analytical Procedure}

Descriptive statistics will be used in analyzing the data collected from the questionnaire. The descriptive statistical tools employed were tables and charts. Linear regression was used in testing the hypotheses. The equations were also subjected to a dynamic estimation, using the lagged structure of the variables. The test of the hypothesis earlier 
stated would be done at $5 \%$ level of significance. While the simple percentage count will be applied for analyzing the biographical data, the second section data will be analyzed using the simple regression analysis, to test the impact of relationships among variables. ANOVA will be used to test the significance of the model.

To derive useful analysis from the data collected, the simple regression model will also be used to test for the relationship and also the degree of association between the independent variable and the dependent variables. These are represented as:

$\mathrm{Y}=\mathrm{f}(\mathrm{X})$

Fraudulent Practice $=\mathrm{f}($ Accountability $)$

Where Fraudulent Practice $(\mathrm{FP})=$ Dependent variable

Accountability $(\mathrm{ACC})=$ Independent variable

The independent variable is then further subdivided into;

Internal Control (IC)

Good Governance (GG)

External Audit (EA)

Regulatory Process (RP)

Specific operationalization variables are shown below

$\mathrm{FP}=\mathrm{f}(\mathrm{IC}) \ldots \ldots \ldots \ldots \ldots \ldots \ldots$ Equation 1

$\mathrm{FP}=\mathrm{f}(\mathrm{GG}) \ldots \ldots \ldots \ldots \ldots \ldots \ldots$ Equation 2

$\mathrm{FP}=\mathrm{f}(\mathrm{EA}) \ldots \ldots \ldots \ldots \ldots \ldots$ Equation 3

$\mathrm{FP}=\mathrm{f}(\mathrm{RP}) \ldots \ldots \ldots \ldots \ldots \ldots \ldots$ Equation 4

A combination of the equation gives the following compound equation;

$\mathrm{FP}=\mathrm{f}(\mathrm{IC}, \mathrm{GG}, \mathrm{EA}, \mathrm{RP})$

1.8. Data Presentation and Analysis

The questionnaire was administered through an electronically enabled platform. However, only 40 respondents provided feedback within the time frame which is approximately fifty-six percent of response rate from the sample. Table 1 . What is your gender

\begin{tabular}{|ll|r|r|r|r|}
\hline & \multicolumn{2}{|c|}{ Frequency } & Percent & Valid Percent & Cumulative Percent \\
\hline \multirow{2}{*}{ Valid } & Male & 34 & 77.3 & 79.1 & 79.1 \\
& Female & 9 & 20.5 & 20.9 & 100.0 \\
Missing & Total & 43 & 97.7 & 100.0 & \\
Total & System & 1 & 2.3 & & \\
\hline
\end{tabular}

From table 1., it shows that majority of the respondents are males which accounted for approximately seventynine percent of the total respondents sampled.

Table 2. What is your professional qualification

\begin{tabular}{|ll|l|l|l|l|}
\hline & & Frequency & Percent & Valid Percent & Cumulative Percent \\
\hline \multirow{3}{*}{ Valid } & ACA & 25 & 56.8 & 58.1 & 58.1 \\
& FCA & 18 & 40.9 & 41.9 & 100.0 \\
& Total & 43 & 97.7 & 100.0 & \\
Missing & System & 1 & 2.3 & & \\
Total & & 44 & 100.0 & & \\
\hline
\end{tabular}

From table 2., it shows that majority of the respondents are ACAs which accounted for approximately fiftyseven percent of the total respondents sampled.

Table 3. What is your highest Education Level

\begin{tabular}{|rl|r|r|r|r|}
\hline & & Frequency & Percent & Valid Percent & Cumulative Percent \\
\hline \multirow{6}{*}{ Valid } & HND & 2 & 4.5 & 4.8 & 4.8 \\
& MSC & 16 & 36.4 & 38.1 & 42.9 \\
& MSC & 21 & 47.7 & 50.0 & 92.9 \\
& PhD & 3 & 6.8 & 7.1 & 100.0 \\
Missing & Total & 42 & 95.5 & 100.0 & \\
Total & System & 2 & 4.5 & & \\
\hline
\end{tabular}

From table 3., it shows that majority of the respondents have a Master's degree qualification which accounted for approximately forty-eight percent of the total respondents sampled. 
Table 4. How long is your work experience

\begin{tabular}{|ll|r|r|r|r|}
\hline & & Frequency & Percent & Valid Percent & Cumulative Percent \\
\hline & 0-5yrs & 13 & 29.5 & 30.2 & 30.2 \\
& 6-10yrs & 3 & 6.8 & 7.0 & 37.2 \\
Valid & $11-15 \mathrm{yrs}$ & 7 & 15.9 & 16.3 & 53.5 \\
& $16-20 \mathrm{yrs}$ & 9 & 20.5 & 20.9 & 74.4 \\
& 21 and above & 11 & 25.0 & 25.6 & 100.0 \\
& Total & 43 & 97.7 & 100.0 & \\
Missing & System & 1 & 2.3 & \\
Total & & 44 & 100.0 & \\
\hline
\end{tabular}

From table 4., it shows that majority of the respondents have between 0-5 years of work experience which accounted for approximately thirty percent of the total respondents sampled.

Table 5. Sector of commerce actively engaged in presently

\begin{tabular}{|ll|r|r|r|r|}
\hline & Frequency & Percent & Valid Percent & Cumulative Percent \\
\hline \multirow{2}{*}{ Vulid } & 4 & 10.0 & 10.0 & 10.0 \\
& Private sector & 28 & 70.0 & 70.0 & 80.0 \\
& Not for profit sector & 2 & 5.0 & 5.0 & 85.0 \\
Self employed & 6 & 15.0 & 15.0 & 100.0 \\
& Total & 40 & 100.0 & 100.0 & \\
\hline
\end{tabular}

From the table 5., it shows that majority of the respondents are engaged in the private sector which accounted for approximately seventy percent of the total respondents sampled.

\subsection{Test of Hypotheses}

Test of Hypothesis One

The below hypothesis was formulated to answer research question one:

$\mathrm{H}_{0}$ : There is no significant relationship between internal audit and fraudulent practices in Nigerian not-for profit making organizations.

Table 6. Model Summary

\begin{tabular}{|l|l|l|l|l|}
\hline Model & R & R Square & Adjusted R Square & Std. Error of the Estimate \\
\hline 1 & $.084 \mathrm{a}$ & .007 & -.017 & 1.14900 \\
\hline
\end{tabular}

a. Predictors: (Constant), Existing internal control systems in Nigerian NGOs are effective in curbing fraudulent practices?

From table 6., it shows that there is low impact of internal control on fraudulent practices in NPOs in Nigeria. This is represented by $7 \%$.

Table 7. ANOVA a

\begin{tabular}{|ll|l|l|l|l|l|}
\hline Model & & Sum of Squares & df & Mean Square & F & Sig. \\
\hline \multirow{2}{*}{1} & Regression & 383 & 1 & .383 & .290 & $.593 \mathrm{~b}$ \\
& Residual & 54.129 & 41 & 1.320 & & \\
& Total & 54.512 & 42 & & & \\
\hline
\end{tabular}

From table 7., it shows that the $\mathrm{p}$ value of 0.593 which is higher than our alpha value set at 0.05 . This therefore means that we are to retain the null hypothesis which says 'There is no significant relationship between internal audit and fraudulent practices in Nigerian not-for profit making organizations.'

Table 8. Coefficients a

\begin{tabular}{|c|c|c|c|c|c|}
\hline \multirow[t]{2}{*}{ Model } & \multicolumn{2}{|c|}{$\begin{array}{l}\text { Unstandardized } \\
\text { Coefficients }\end{array}$} & $\begin{array}{l}\text { Standardized } \\
\text { Coefficients }\end{array}$ & \multirow[t]{2}{*}{$\mathrm{t}$} & \multirow[t]{2}{*}{ Sig. } \\
\hline & B & Std. Error & Beta & & \\
\hline (Constant) & 2.927 & .511 & & 5.725 & .000 \\
\hline $\begin{array}{l}\text { 1Existing internal control systems in Nigerian NGOs are } \\
\text { effective in curbing fraudulent practices? }\end{array}$ & .088 & .163 & .084 & .539 & .593 \\
\hline
\end{tabular}

From table 8., it shows that there is a form of relationship between the variables (IC and FPs). This is represented by $59.3 \%$.

Test of Hypothesis Two

The below hypothesis was formulated to answer research question two:

$\mathrm{H}_{0}$ : Good governance does not have any significant relationship with fraudulent practices being carried out in 
Nigerian NPOs.

Table 9. Model Summary

\begin{tabular}{|l|l|l|l|l|}
\hline Model & $\mathrm{R}$ & R Square & Adjusted R Square & Std. Error of the Estimate \\
\hline 1 & $.024 \mathrm{a}$ & .001 & -.024 & 1.15977 \\
\hline
\end{tabular}

a. Predictors: (Constant), Do you agree that strong governance practice within NGOs will aid in preventing fraudulent practices

From table 9., it shows that there is a minimal impact of good governance on fraudulent practices in Nigerian NPOs. This is represented by $1 \%$

Table10. ANOVA a

\begin{tabular}{|ll|l|l|l|l|l|}
\hline Model & & Sum of Squares & df & Mean Square & F & Sig. \\
\hline \multirow{3}{*}{1} & Regression & 031 & 1 & .031 & .023 & $.880 \mathrm{~b}$ \\
& Residual & 53.802 & 40 & 1.345 & & \\
& Total & 53.833 & 41 & & & \\
\hline
\end{tabular}

From table 10., it shows that the $p$ value of 0.880 which is higher than our alpha value set at 0.05 . This therefore means that we are to retain the null hypothesis which says 'good governance does not have any significant relationship with fraudulent practices being carried out in Nigerian NPOs'. This is contrary to the public view from our study where most respondent think good governance can actually curb fraudulent practices.

Table 11. Coefficients a

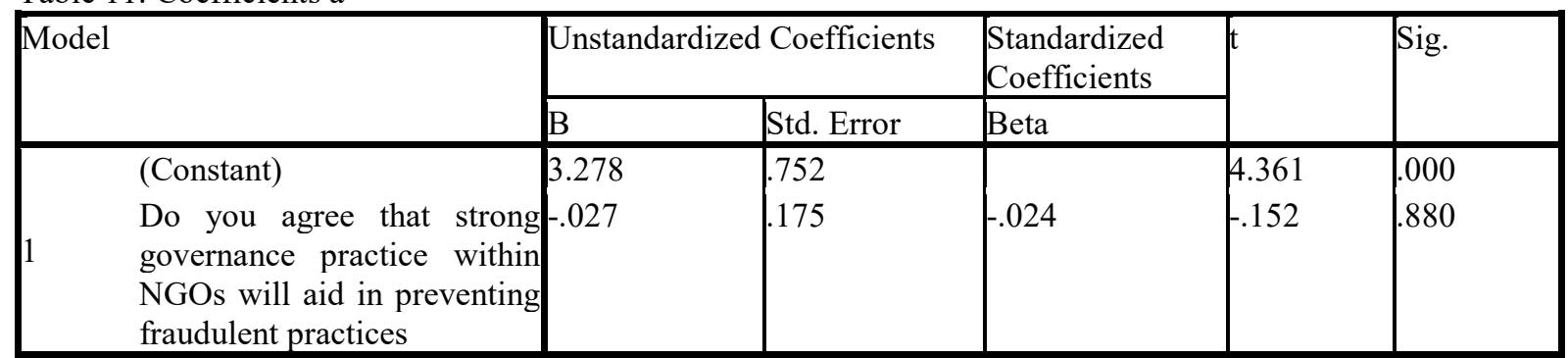

From table 11., it shows that there is a strong form of relationship between the variables (GG and FP). This is represented by 0.880 .

Test of Hypothesis Three

The below hypothesis was formulated to answer research question three:

$\mathrm{H}_{0}$ : There is no significant relationship between external audit and fraudulent practices among NPOs in Nigeria. Table 12. Model Summary

\begin{tabular}{|l|l|l|l|l|}
\hline Model & R & R Square & Adjusted R Square & Std. Error of the Estimate \\
\hline 1 & $.189 \mathrm{a}$ & .036 & .012 & 1.13224 \\
\hline
\end{tabular}

From table 12., it shows that there is a little impact of external audit on fraudulent practices in Nigerian NPOs. This is represented by $36 \%$

Table 13. ANOVA a

\begin{tabular}{|ll|l|l|l|l|l|}
\hline Model & & Sum of Squares & df & Mean Square & F & Sig. \\
\hline \multirow{3}{*}{1} & Regression & 1.951 & 1 & 1.951 & 1.522 & $.224 \mathrm{~b}$ \\
& Residual & 52.561 & 41 & 1.282 & & \\
& Total & 54.512 & 42 & & & \\
\hline
\end{tabular}

From table 13., it shows that the $\mathrm{p}$ value of 0.224 which is higher than our alpha value set at 0.05 . This therefore means that we are to retain the null hypothesis which says 'there is no significant relationship between external audit and fraudulent practices among NPOs in Nigeria. This is consistent with the public view from our study where most respondent think that there is a positive impact of external audit in curbing fraudulent practices. Table 14. Coefficients a

\begin{tabular}{|c|c|c|c|c|c|}
\hline \multirow[t]{2}{*}{ Model } & \multicolumn{2}{|c|}{$\begin{array}{l}\text { Unstandardized } \\
\text { Coefficients }\end{array}$} & $\begin{array}{l}\text { Standardized } \\
\text { Coefficients }\end{array}$ & \multirow[t]{2}{*}{$t$} & \multirow[t]{2}{*}{ Sig. } \\
\hline & $\mathrm{B}$ & Std. Error & Beta & & \\
\hline (Constant) & 2.443 & .626 & & 3.901 & .000 \\
\hline $\begin{array}{l}\text { 1Do you agree that external audits will assist in detecting } \\
\text { fraudulent practices in NGOs? }\end{array}$ & .184 & .149 & .189 & 1.234 & .224 \\
\hline
\end{tabular}

From table 14., it shows that there is a low form of relationship between the variables (EA and FP). This is represented by 0.224 . 
Test of Hypothesis four

The below hypothesis was formulated to answer research question four:

$\mathrm{H}_{0}$ : Regulatory process does not have a significant relationship with fraudulent practices among NPOs in Nigeria. Table 15. Model Summary

\begin{tabular}{|l|l|l|l|l|}
\hline Model & $\mathrm{R}$ & R Square & Adjusted R Square & Std. Error of the Estimate \\
\hline 1 & $.063 \mathrm{a}$ & .004 & -.020 & 1.15074 \\
\hline
\end{tabular}

From table 15., it shows that there is very little or no impact of a regulatory body on fraudulent practices in Nigerian NPOs. This is represented by $0.4 \%$.

Table 16. ANOVA a

\begin{tabular}{|ll|l|l|l|l|l|}
\hline Model & & Sum of Squares & df & Mean Square & F & Sig. \\
\hline \multirow{3}{*}{1} & Regression & 219 & 1 & .219 & .165 & $.686 \mathrm{~b}$ \\
& Residual & 54.293 & 41 & 1.324 & & \\
& Total & 54.512 & 42 & & & \\
\hline
\end{tabular}

From table 16., it shows that the $\mathrm{p}$ value of 0.6 .6 which is higher than our alpha value set at 0.05 . This therefore means that we are to retain the null hypothesis which says 'regulatory process does not have a significant relationship with fraudulent practices among NPOs in Nigeria'. This is contrary to the public view from our study where most respondent think that there is a positive impact of regulatory process in curbing fraudulent practices. Table 17. Coefficients a

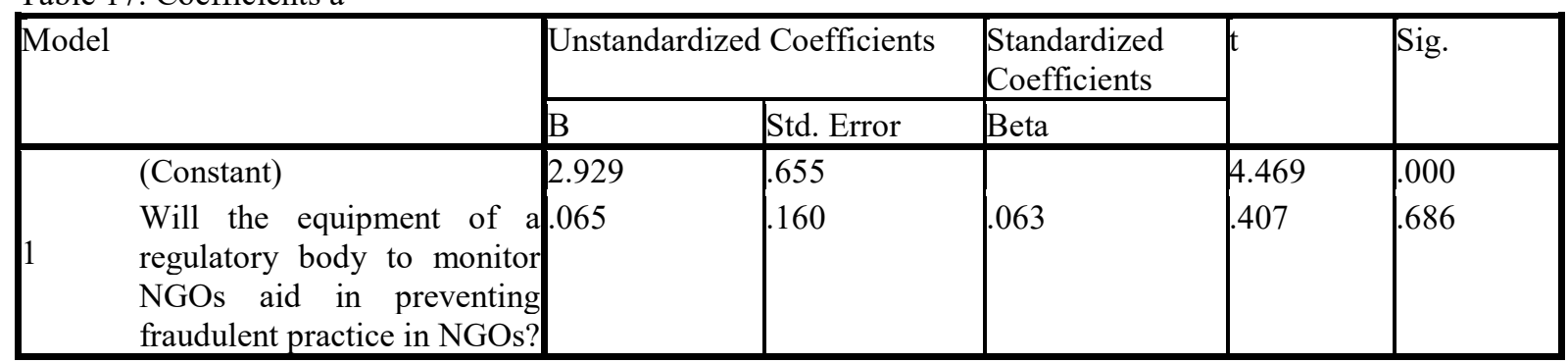

From table 17., it shows that there is a weak form of relationship between the variables (RP and FP). This is represented by 0.686 .

\section{Discussion of Findings}

Our findings from the regression analysis show that there is a minimal impact of internal audit on fraudulent practices in NPOs. This is represented by $7 \%$. On the other hand, respondents mostly agreed on the relevance of internal audit in curbing fraudulent practices in NPOs. This is slightly not consistent with the retaining of the null hypothesis 'There is no significant relationship between internal audit and fraudulent practices in Nigerian not-for profit making organizations.' This is in line with the study of Ojua, (2016) which stated that internal audit and control system in NPOs where based on trust and hence watering down their effectiveness. From our study, the regression analysis show that there is a minimal impact of good governance on fraudulent practices in NPOs. This is represented by $1 \%$. On the other hand, respondents mostly agreed that good governance will aid in curbing fraudulent practices in NPOs and that the code of governance 2016 produced by the financial reporting council of Nigeria if practiced will help in curbing fraudulent practice occurrence. This is contrary with the retention of the null hypothesis 'good governance does not have any significant relationship with fraudulent practices being carried out in Nigerian NPOs' The finding align with the perspectives of Greenlee et al, (2007) which study observed that despite the existence governance structure, fraudulent practices were being carried out by those in the helms of governance.

On the third research questions the findings indicate that there is a little impact of external audit on fraudulent practices in NPOs. This is represented by $36 \%$ which exhibits the highest relationship among the four variables in review on fraudulent practices. On the other hand, respondents mostly agreed that external audit will aid in curbing fraudulent practices in NPOs. This is inconsistent with the retention of the null hypothesis 'there is no significant relationship between external audit and fraudulent practices among NPOs in Nigeria.' This brings out the uniqueness of this study with most existing literature focusing on internal audit and control and governance, this study also adopted the culture of external audit as found in the profit making organization to examine if it will curb fraudulent practices in NPOs. Although, result from the hypothesis testing shows that there is no relationship between the two but from the co-efficient table, it shows that there is a strong form of relationship between the two but due to other reasons making the external audit a mere rubber stamp will reduce the impact of external audit on curbing fraud in among NPOs. From our study, the regression analysis show that there is a very insignificant impact of external audit on fraudulent practices in NPOs. This is represented by $0.04 \%$. On the other hand, respondents mostly agreed that regulatory process will aid in curbing fraudulent practices in NPOs. This is 
contrary with the retention of the null hypothesis 'regulatory process does not have a significant relationship with fraudulent practices among NPOs in Nigeria'

\section{Conclusion and Recommendation}

This study is aimed seeking ways in reducing fraudulent practices in NPOs in Nigeria through improved accountability. Accountability process was broken into four component parts namely internal audit, governance, external audit and the regulatory process. Two theories were reviewed on which this study is hinged on which are the lending credibility theory and the fraud triangle theory. Some existing literatures were reviewed and relevant concepts discussed. Forms of fraudulent practices were also highlighted which are: conversion of NPOs asset to personal use, fictitious vendor/ suppliers transaction and fraudulent financial reporting Based on the findings of this study, internal audit, good governance structure and the regulatory process were seen not to have significant impact relationship on the fraudulent practices carried out in NPOs in Nigeria which is consistent with previous studies. Though external audit is seen to have a significant impact in curbing the fraudulent practices in NPOs in Nigeria. The reason is not far-fetched as they are professionals who have their names to protect and will not easily compromise standard and hence in the event of carrying out audit assignment might detect this fraudulent practices. In addition, they are independent and will not be easily manipulated.

In conclusion, this study has a paradigm shift from existing literature in that internal audit and governance were not only examined but also external audit, the Nigerian code of governance for NPOs 2016 and the regulatory process were also examined in a bid to curb fraudulent practices in NPOs in Nigeria. Amongst all these variables, external audit is perceived to have more impact on the cut tailing of fraudulent practices. Though respondents are of the view that all the highlighted variables will curb fraudulent practices. From our study, the most widely identified fraudulent practice in Nigerian NPOs is the conversion of NPOs assets to personal use.

Based on our findings, we therefore recommend the following:

The mandatory use and practice of the Nigerian code of corporate governance 2016 which existence has not been elaborate. As this code was developed to ensure good governance which takes care of the need of various stakeholders in line;

Enforcement of external audit just like the profit making sector to help in reducing the activity of fraud by the performance of the audit exercise which is also in line with the lending credibility; \&

There should be rules to ensure the close monitoring of NPOs asset by setting monitoring rules. This is in line with the findings of this study and the fraud triangle theory where those in governance due to pressure might convert NPOs asset for their own personal use.

\section{References}

Bourke, N. M. (2006). Are attributes of corporate governance related to the incidence of fraudulent financial reporting? New Zealand: The university of Waikato.

Burnaby, P. A., Howe, M. A., \& Muchlmann, B. W. (2011). Detecting fraud in the organization: An internal audit perspective.

Dzomira. (2014). Internal control and fraud schemes in nonprofit organizations. A guide for good practice. Research Journal of Finance and Accounting, 5(2), 118-124.

Etengu, R. O., \& Amony, M. (2016). Internal control system and financial performance in Non-Governmental. International Journal of Contemporary Applied Sciences, 328-347.

Greenlee, J., Fischer, M., \& Keating, E. (2001). An investigation of fraud in nonprofit organizations: Occurences and deterrents. Non Profit and Voluntary Sector Quarterly, 676-694.

Morehead, W. M. (2007). Internal control and governance in non governmental organizations designed to provide accountability and deter, prevent and detect fraud and corruption . Mississp1, United states of Amreica.

Ojua, M. O. (2016). Internal Controls and Fraud Prevention in Non-profit Organizations: A Survey of Selected Churches in Lagos, Nigeria. International Journal of Business and Management, 4(6), 240-247.

Okaro, S. C., Okafor, G. O., \& Ofoegbu, G. (2013). Corporate fraud in Nigeria-A two case study. International Journal of Research in Management, 9-17.

Okaro, S., \& Okafor, O. (2009). Creative Accounting, Corporate Governance Watch dog Institutions and SystemsThe Case of Cadbury(Nig.) Plc. 1-12.

Osaze, E. (2011). The specificities of value melt down in the Nigerian Stock 2008-2010. In professoral chair lecture (pp. 1-19). Benin: University of Benin.

Otieno, S., \& Nyangechi, E. O. (2013). Effectiveness of internal control procedures on management efficiency of Free Primary Education Funds: a case of Public Primary schools in Kisii central District, Kenya. Journal of Sociology and Social Work, 22-41. 